\title{
RESPONSE OF GIZA 90 COTTON CULTIVAR TO FOLIAR APPLICATION OF SOME DROUGHT TOLERANCE INDUCERS UNDER WATER STRESS AND HIGH TEMPERATURE CONDATIONS IN UPPER EGYPT \\ Hamoda, S. A. F. \\ Agronomy Res. Section, Cotton Res. Inst., Agric. Res. Center, Giza, Egypt
}

\begin{abstract}
Two field experiments were carried out in El-Mattana Agric. Res. St., Agric. Res. Cent., Luxor Governorate, Egypt during 2010 and 2011 seasons to study the response of Giza 90 cotton cultivar to the application of some drought tolerance inducers to increase the tolerance of cotton plants to drought under high temperature condations in Upper Egypt. The experimental design was a split plot with four replications. Main plots included two irrigation intervals (15 and 21 days) and sub plot included the foliar application of four drought tolerance i.e CaBoron, Pix, Humex and Methanol) and a control (untreated plants), The obtained results could be summarized as follows: Irrigation every 15 day significantly increased plant height, no. of fruiting branches/plant, no. of days to first flower and first open boll. Prolonging irrigation interval to 21 day significantly decreased no. of open bolls /plant, boll weight, seed index, seed cotton yield/fed., fiber length, uniformity index and fiber strength, but lint \% was significantly increased. All drought tolerance inducers significantly increased plant height, number of fruiting branches and open bolls/plant, boll weight, seed index, seed cotton yield /fed., earliness \%, fiber length, uniformity index and fiber strength as compared with the untreated plants. In general, plants which were sprayed with methanol gave the highest averages of growth, yield and its components and earliness \%, followed by plants which were sprayed with CaBoron, while the Pix sprayed plants came the last in this respect in both seasons. Well watered plants every 15 day showed greater response to Methanol than to any other drought tolerance inducer, while the plants irrigated every 21 day and treated with pix gave the lowest average in this respect. The interaction between studied factors had a significant effect on fiber strength in both seasons and upper half mean length in the first season only. Finally it could be concluded from this study that the CaBoron, Humex, Pix and Methanol applications to plants under normal and water stress conditions could induce drought tolerance of cotton plants and in turn improved plant growth, fruiting and yield particularly under water stress and high temperature conditions.

Keywords: Cotton, Irrigation intervals, Pix, Humex, CaBoron, Methanol, Growth,
\end{abstract} Earliness, Yield and Fiber

\section{INTRODUCTION}

Crop growth and yield are controlled by environmental factors (light, $\mathrm{CO}_{2}$, temperature, water, nutrients, etc.). Water is generally considered the most limiting factor in higher plants than any other single environmental factor. Exposing cotton plants to water stress particularly during the flowering stage adversely affected plant growth and productivity (Kassem and Namich, 2003 and Meek et al., 2003). 
Hamoda, S. A. F.

Therefore, it seems imperative to work for improving water use efficiency for major crops including cotton which could be achieved by searching some means helping in promoting drought tolerance. In cotton attempts have been made to avoid adverse effects caused by water stress through making use of osmotic adjustment (Ashraf and Foolad, 2007). Cotton plant, however, reacts strongly to soil moisture conditions and the proper water supply during different stages of plant growth and development. Water deficiency particularly during fruiting stage markedly restricts over all plant growth, fruit retention and hence seed cotton yield (El-Sayed, 2005 and Hamed, 2007). Regardless of water availability, even well irrigated cotton plants usually experience some degree of water stress, particularly at midday time, due to high evapotranspirative conditions, like those prevailing in Upper Egypt, where short-duration mild water stress could damage cotton yield (Reddy et al., 1998). This confirms the need for enhancing cotton tolerance to water stress. Ahmed and Kassem (2008) found that irrigation interval every 3 weeks resulted in significant reduction in plant height, no. of fruiting branches and open bolls/plant and seed cotton yield/fed. Gebaly (2007) and Hamoda, (2010) found that prolonging the irrigation interval to 21 day resulted in significant reduction in plant height, no. of fruiting branches/plant, days to first flower and first open boll, no. of open bolls/plant, boll weight, seed index, seed cotton yield/fed. and gave low fiber quality.

El-Beily, et al. (2001) found that application of pix four times significantly reduced plant height and number of fruiting branches/plant. ElTabbakh (2002) found that Pix at concentrations up to $3 \mathrm{~L} /$ ha decreased plant height, lint \%, while significantly increased the number of fruiting branches and total bolls/plant, seed index, seed cotton yield/ha. and earliness \%. Kassem and Namich (2003) found that spraying cotton plants with pix decreased plant height but increased number of open bolls/plant and seed cotton yield/fed. Buttar and Navneet (2004) found that Pix reduce plant height but increase numbers of sympodia branches and bolls/plant, seed index, boll weight and seed cotton yield/fed. Kumar, et al. (2005) found that spraying Pix at 90 days on hybrid cotton reduced plant height, leaf area but stimulated the photosynthesis which resulted in higher yield and heavier boll weight. Muhammad, et al. (2007) found that application Pix significantly reduced plant height, but increased the seed index, number of open bolls and seed cotton yield/fed. Abdel Aal et al. (2011) found significant increase in number of sympodial branches and open bolls/plant, boll weight, seed index, earliness $\%$ and seed cotton yield/fed. due to foliar application of pix at the rate of $1 \mathrm{ml} /$ liter twice at start of flowering and 30 days later compared to untreated plants.

Foliar application of Methanol had been reported to increase the yield and reduce the water requirements of $\mathrm{C}_{3}$ crops in warm and high radiation arid climate. Nonomura and Beson (1992) reported that one of the important effects of Methanol as a precursor of $\mathrm{CO}_{2}$ on the cotton plants is increase water use efficiency under intense sunlight conditions, due to increased turgidity which leads to a reduction in transpiration. They also explained this effect as a response to an increase in sugar content due to the utilization of Methanol as source of carbon. The availability of carbon in the vicinity of the leaf enhances the photosynthesis rate. Plants treated 
with methanol stood erect and vigorous seven days after irrigation at the flowering stage while untreated plants showed water stress dropping symptoms, the treated plants reached that stage two days later. This result showed that under conditions where water supply is a limiting factor for yield improvement, the use of Methanol could significantly increase yield.

Benefits are of particular importance in Egypt to increase seed cotton yield and decrease the irrigation water consumed in summer season by cotton plant mean while, Abdel Al (1998) found that Methanol did not show phototoxic symptoms at any of the given concentrations, the treatments of Methanol increased significantly plant height, leaf area, dry weight of cotton parts, number of bolls/plants, seed index and seed cotton yield /fed. by using 10, 20 and $30 \%$ aqueous solution of Methanol during flowering period. He added that there was no significant effect on the number of fruiting branches, boll weight, lint $\%$ and earliness \%. On the other hand Moseley et al. (1994) evaluated the effect of Methanol $30 \%$ on growth of cotton under dry land and irrigated conditions and found that Methanol had no significant effect on growth and cotton biomass production. Barnes and Houghton (1994) found that Methanol increased boll number and fruiting sites of cotton plants but lint yield was adversely affected. Gebaly (2007) found that Methanol increased number of fruiting branches and open bolls/plant, boll weight, seed index, lint \%, seed cotton yield/fed., fiber fineness, strength and fiber length.

Boron (B) has been universally recognized as the most important micronutrient for cotton production, and cotton plant requires $B$ in relatively large amounts as compared with other plants (Niaz et al., 2002 and Roberts et al., 2000). Boron helps in the biosynthesis of cell walls, and thereby cell division and elongation, in the rapidly growing, conductive and storage tissues; and also aids in sugars and nutrients translocation, resulting in promoting growth of vegetative growing tissues and developing storage sinks (Blevins and Lukaszewski, 1998). Cotton plant shows a particular need for B during flowering and boll development stage owing to the central role of $B$ in stimulating pollen germination and pollen tube growth, resulting in successful fruit setting (Niaz et al., 2002 and Zhao and Oosterhuis, 2003). Many recent studies have demonstrated positive effects of foliar application of B on cotton growth, fruit retention, yield and yield components of cotton in Egypt (Saeed, 2000 and El-Menshawi and El-Sayed, 2007). El- Shazly et al. (2003) found that foliar feeding with $B$ treatments gave the highest values of leaf $N, P, K$, $\mathrm{Mg}, \mathrm{B}, \mathrm{Fe}, \mathrm{Mn}$, and $\mathrm{Zn}$ contents and significantly increased plant height, number of fruiting branches and total bolls set/plant, earliness \% and seed cotton yield and its components as compared with the control. Kassem, et al. (2009) found that spraying boron showed some positive effects on cotton which significantly increased plant height, number of fruiting branches and open bolls/plant, boll weight and seed cotton yield/fad.

Although potassium $\mathrm{K}$ isn't a structural component of plants, it is one of most important nutrients with respect to its physiological and biochemical functions. K plays an important role in many of the vital physiological processes in the plant, such as transpiration, translocation of sugars and starch, protein formation and osmotic regulation. Several enzymes systems requiring potassium e.g. nitrate reductase, pyruvate, kinase and activation of 
Hamoda, S. A. F.

ATP use systems. Potassium is an essential macro element for all living organisms and is required in large amounts for normal plant growth and development. Etidal, et al (1997) found that spraying cotton plants with $48 \%$ $\mathrm{K}_{2} \mathrm{O}$ at the rate of $9 \mathrm{~kg} / \mathrm{fed}$. increased seed cotton yield/fed. due to the increased in number of open bolls/plant and boll weight. El- Shazly et al. (2003) found that foliar feeding with $\mathrm{K}$ at two levels $\left(1 \%\right.$ and $2 \% \mathrm{~K}_{2} \mathrm{O}$ ) significantly increased number of fruiting branches and open bolls/plant, seed index, lint \%, boll weight, earliness \% and seed cotton yield /fed. Abdel Aal, et al (2011) found that foliar application $\mathrm{P}$ and $\mathrm{K}$ significantly increased number of sympodial branches and open bolls/plant, boll weight, seed index, earliness $\%$ and seed cotton yield /fed.

\section{MATERIALS AND METHODS}

The field experiments were conducted in El-Mattana Agricultural Station, Luxor Governorate during two growing seasons (2010 and 2011) to investigate the response of Giza 90 cotton variety to irrigation intervals (irrigation every 15 and 21 day throughout the growing season starting after the first irrigation) and four drought tolerance inducers (CaBoron, Pix, Humex and Methanol) compared with control (untreated plants) under high temperature in Upper Egypt. The experimental design was a split plot with four replications. Main plots included the irrigation intervals and the sub plots included the drought inducing treatments the control.

\begin{tabular}{|l|l|c|}
\hline Trade name & \multicolumn{1}{|c|}{ Active ingredient } & Rates \\
\hline CaBoron & $1.5 \%$ Boron $+12 \%$ Potassium Oxide $\left(\mathrm{K}_{2} \mathrm{O}\right)+6 \%$ Calcium & $0.5 \mathrm{~cm} / \mathrm{later}$ \\
\hline Pix & 1,1 dimethyl piperidinium chloride (mepiquat chloride ) & $500 \mathrm{~cm}^{3} / \mathrm{fed}$ \\
\hline Methanol & Methyl Alcohol, $\mathrm{CH}_{3} \mathrm{OH}$ & $10 \%$ \\
\hline Humex & $60 \%$ Humic Acid $-15 \%$ Fulvic Acid $-10 \%$ Potassium Oxide $\left(\mathrm{K}_{2} \mathrm{O}\right)$ & $2.5 \mathrm{~cm} / \mathrm{later}$ \\
\hline
\end{tabular}

All chemical application under normal irrigation and water stress were sprayed three times at squaring, beginning of flowering and 2 weeks later.

The experimental unit included 7 ridges $(5 \mathrm{~m}$ long and $65 \mathrm{~cm}$ apart) occupying an area of $22.75 \mathrm{~m}^{2}$. Cotton seeds were planted on 23rd and 24th of March in 2010 and 2011 seasons, respectively. Hills were spaced at $25 \mathrm{~cm}$ within rows and seedlings were thinned at 2 plants/hill after 35 day from planting. Phosphorus fertilizer as ordinary superphosphate $\left(15.5 \% \mathrm{P}_{2} \mathrm{O}_{5}\right)$ at the rate of $22.5 \mathrm{~kg} \mathrm{P} \mathrm{P}_{5}$ /fed. was incorporated during seed bed preparation. Nitrogen fertilizer in the form of ammonium nitrate $(33.5 \% \mathrm{~N})$ at the rate of 60 $\mathrm{kg} \mathrm{N} / \mathrm{fed}$. was applied in two equal doses, immediately before the first and the second irrigations. Potassium fertilizers in the form of potassium sulfate (48\% $\mathrm{K} 2 \mathrm{O}$ ) at the rate of $24 \mathrm{~kg} \mathrm{K2O} / \mathrm{fed}$. was side-dressed in a single dose before the second irrigation. The preceding crop was sugarcane (Saccharum spp.) in 2010 and 2011 seasons. Standard agricultural practices were followed throughout the growing seasons. All samples were taken at random from each sub plot in order to study growth and yield traits. During flowering and bolling stages, number of days from planting to first flower and first open boll were recorded as a mean of five plants of the second ridge. At harvest, 6 
guarded plants were randomly taken from the central ridge to determine plant height $(\mathrm{cm})$, number of fruiting branches/plant, number of open bolls/plant, boll weight (gm), lint \% and seed index (gm). Seed cotton yield (ken./fed.) was estimated as the weight of seed cotton yield (kilogram) picked from the five central ridges collected from two picks, then converted to yield per fedden in kentar $($ Kentar $=157.5 \mathrm{~kg}$.). Earliness percentage $(E \%)$ was determined as percent of seed cotton yield of first pick to total seed cotton yield. The studied fiber quality traits were fiber length (upper half mean length UHM mm.), fiber strength ( $\mathrm{g} / \mathrm{tex}$.) and micronaire value which were measured by using High Volume Instrument (HVI) according to A.S.T.M. (1986). Climatic conditions were monitored by the Department of Meteorology, Agricultural Research Center. Maximum, minimum and mean air temperatures $\left({ }^{\circ} \mathrm{C}\right)$ and maximum and minimum air humidity $\%$ are shown in (Table. 2), These measurements were recorded in monthly intervals through the cotton growing season (March-September) in 2010 and 2011 seasons for El-Mattana Agricultural Station. Representative soil samples were taken from the experimental sites before sowing in the two seasons and were prepared for analysis, according to Chapman and Pratt (1978). The results of the soil analysis are shown in Table (1). All collected data were subjected to statistical analysis as proposed by Gomez and Gomez (1984) and means were compared by LSD at $5 \%$ level of probability

Table (1): Soil analysis of the experimental site in the two growing seasons

\begin{tabular}{|c|c|c|c|c|c|c|c|c|c|c|c|c|}
\hline \multirow{3}{*}{ Seasons } & \multicolumn{12}{|c|}{ Properties } \\
\hline & \multirow{2}{*}{ Texture } & \multirow{2}{*}{ pH } & \multirow{2}{*}{$\begin{array}{c}\text { EC Mmhos } \\
/ \mathrm{cm} .\end{array}$} & \multirow{2}{*}{$\begin{array}{c}\mathrm{CaCO}_{3} \\
\%\end{array}$} & \multicolumn{8}{|c|}{ Available element ppm } \\
\hline & & & & & $\mathbf{N}$ & $\mathbf{P}$ & $\mathrm{K}$ & $\mathrm{Fe}$ & Mn & $\mathrm{Zn}$ & $\mathrm{Cu}$ & B \\
\hline 2010 & Clay loam & 7.4 & 0.26 & 2.9 & 64 & 11 & 385 & 12.4 & 16.4 & 2.2 & 4.0 & 0.45 \\
\hline 2011 & Clay loam & 7.6 & 0.22 & 3.1 & 61 & 10 & 336 & 13.5 & 8.6 & 1.7 & 3.3 & 0.40 \\
\hline
\end{tabular}

Table (2): Mean monthly air temperatures and humanity \% for ElMattana Agricultural Station, Luxor Governorate during the two growing seasons

\begin{tabular}{|c|c|c|c|c|c|c|c|c|c|c|c|c|}
\hline \multirow{3}{*}{ Month } & \multicolumn{6}{|c|}{2010 season } & \multicolumn{6}{|c|}{2011 season } \\
\hline & \multicolumn{3}{|c|}{ Air temperature $\mathbf{C}^{0}$} & \multicolumn{3}{|c|}{ Humidity\% } & \multicolumn{3}{|c|}{ Air temperature $\mathbf{C}^{0}$} & \multicolumn{3}{|c|}{ Humidity\% } \\
\hline & Max. & Min. & Mean & Max. & Min. & Mean & Max. & Min. & Mean & Max. & Min. & Mea \\
\hline Mar & 29.31 & 12.14 & 20.73 & 64.86 & 26.00 & 45.43 & 31.54 & 10.02 & 20.79 & 62.29 & 21.43 & 36 \\
\hline April & 34.91 & 14.16 & 24.53 & 61.30 & 22.50 & 41.90 & 30.42 & 10.37 & 20.40 & 61.43 & 23.93 & 42.68 \\
\hline May & 38.31 & 15.04 & 26.68 & 61.45 & 20.74 & 41.10 & 36.25 & 17.39 & 26.82 & 61.68 & 24.77 & 43.23 \\
\hline June & 40.41 & 14.49 & 27.45 & 62.38 & 24.00 & 43.19 & 29.37 & 20.45 & 29.90 & 62.41 & 24.41 & 43.48 \\
\hline July & 40.93 & 14.34 & 27.64 & 65.39 & 24.36 & 44.87 & 41.02 & 21.17 & 31.10 & 61.81 & 22.64 & 42.23 \\
\hline August & 41.79 & 15.52 & 28.65 & 63.42 & 81 & 44.11 & 40 & 90 & 30.64 & 63.10 & 25.74 & 44.42 \\
\hline SepteI & 39.34 & 17.85 & 28.60 & 68.25 & 25.00 & 46.63 & 35.96 & 17.80 & 26.88 & 64.00 & 25.13 & 44.56 \\
\hline Mean & 38.89 & 14.90 & 26.90 & 63.38 & 23.54 & 43.46 & 37.13 & 17.73 & 27.43 & 62.27 & 24.26 & 43.27 \\
\hline
\end{tabular}

\section{RESULTS AND DISCUSSION}

\section{1- Growth parameter and earliness traits:-}

\section{1.a. Effect of irrigation interval:}

Data in Table (3) reveal that the irrigation intervals over seasons significantly affected plant height, no. of fruiting branches/plant, days to first 
Hamoda, S. A. F.

flower, days to first boll and earliness \%. Irrigation every 15 day increased plant height, no. of fruiting branches/plant, no. of days to first flower and first open boll as compared with irrigation every 21 day. The reduction in plant height due to water deficit may be due to the irregularity of physiological processes induced by water deficit (Makram et al., 1996) and to the effect on biosynthesis of GA content which affected cell expansion (Ibrahim and Moftah, 1997). In this concern, Makram et al. (1996) reported that during the vegetative stage, cotton plants needed closely irrigation interval in order to build the frame work of the cotton plants. In addition, Ibrahim and Moftah, (1997) found that severe water deficit decreases the photosynthetic pigments and endogenous phytohormones namely IAA and cytokinin which are considered main reasons of the unfavorable growth and consequently low productivity. The reduction in plant growth in case of longer irrigation cycles could be in part due to limiting the plant ability to absorb nutrients needed for optimal growth and development of the plant. Also, it is well recognized that water is not only required for different biochemical activities of all cells, but also water-generated trigger pressure in a driving force of cell expansion (Xiong and Zhu, 2002). Thus water deficit disrupts normal cellular activities and restricts plant growth. Previous researches indicated that vegetative growth of cotton plant is in close relation with the amount of irrigation water applied (EL-Sayed, 2005 and Hamed, 2007). The data in Table (2) indicated that the maximum air temperature through fruiting development exceeded the high extremes especially in the first season, in addition the moderate averages of relative humidity which maximize the evapotranspiration. These data cleared that both vegetative and fruiting stages need closely irrigation intervals to meet the high water requirements of cotton plant to water under high air temperatures

\section{1.b. Effect of drought tolerance inducers:}

The results presented in Table (3) showed also that chemical treatments had a significant effect on growth parameters (plant height and number of fruiting branches /plant), earliness traits (days to first open boll and earliness $\%$.) in both seasons and days to first flower in the first season only, while it did not exhibit any significant effect on first fruiting node in both seasons. All chemical treatments (CaBoron, Humex, Pix and Methanol applications) showed significant increase in plant height and earliness traits as compared with untreated plants in both seasons. In general, plants which sprayed with Methanol gave the highest averages of growth parameters and earliness \%, while those sprayed with Pix decreased growth parameters in both seasons. The reduction in plant height due to pix application could mainly due to reduction of internode length and this reduction might be due to the inhibitory effect of pix on the synthesis of gibberellins which have a role in all division and cell expansion (Reddy et al., 1990 and Ahmed, 1994). 
J. Plant Production, Mansoura Univ., Vol. 3 (3), March, 2012 3 
Hamoda, S. A. F.

This effect may be attributed to that auxin may catalyze the hardening of the cell wall thus leading to a shorter cell duration growth and hence a shorter final cell wall length (Girgis et al., 1993). Moreover, Ibrahim and Moftah (1997) reported that the ability of pix to counteract the apical dominance could be due to the reduction in auxin transport to bud sites caused by increasing cytokinin concentration which restricted transport of auxin to axillary buds and subsequently bud out growth has been demonstrated for cotton. The increment of dry matter is attributed to the effect of pix in delaying leaf chlorophyll degradation and increasing its content in cotton leaf which enhances photosynthesis, (Gausman et al. 1981). The favourable effect of foliar feeding with CaBoron could mainly attributed to that the available $\mathrm{B}$ content in the experimental sites low as shown in Table (1).

\section{1.c. Interaction effect:}

Data presented in Table (3) show that the interaction between irrigation intervals and chemical treatments had a significant effect on growth parameters (plant height and number of fruiting branches /plant) and earliness traits (days to first open boll and earliness \%.), while it did not exhibit any significant effect first fruiting node and days to first flower in both seasons. Well watered plants every 15 day which were sprayed with methanol gave the highest average of plant height, number of fruiting branches and earliness \%, while water-stressed plants (21 day interval) treated with pix gave the lowest average of plant height and number of fruiting branches under high temperatures in Upper Egypt. These plants became compact with less number of fruiting branches Meek et al. (2003), found that water stress reduced photosynthesis and hence could account for the reduced cotton plant growth attributes observed herein

\section{Yield and its components:}

\section{2.a. Effect of irrigation interval:}

Data presented in Table (4) show that irrigation intervals had a significant effect on boll weight, number of open bolls /plant, lint \%, seed index and seed cotton yield /fed. in both seasons. Prolonging irrigation interval to 21 day significantly decreased no. of open bolls /plant, boll weight, seed index and seed cotton yield/fed., while lint \% was significantly increased. The reduction in yield and its components owing to extending irrigation interval (water stress) is a logical result of the reduction of nutrient uptake, photosynthesis, vegetative growth and hence the yield capacity of plants. Similar results were obtained by EL-Sayed (2005), Gebaly (2007) and Hamoda (2010). It is clear from results mentioned previously that yield and its components were adversely affected by water stress. Such effects is mainly due to the effects of water stress on certain physiological functions i.e., stomatal conductance, photosynthesis and transpiration. Meek et al. (2003), found that water stress decreased stomatal conductance to $\mathrm{CO}_{2}$ and $\mathrm{H}_{2} \mathrm{O}$ and that the major reason that water stress reduced photosynthesis was its effect on the light reaction of the process. 
J. Plant Production, Mansoura Univ., Vol. 3 (3), March, 2012

4 
Hamoda, S. A. F.

\section{2.b. Effect of drought tolerance inducers:}

Data in Table (4) also show that chemicals treatments had a significant effect on boll weight, number of open bolls /plant, lint \%, seed index and seed cotton yield /fed. in both seasons. All chemical treatments (CaBoron, Humex, Pix and Methanol applications) showed significant increase in yield and its components (boll weight and number of open bolls) as compared with untreated plants in both seasons. In general, plants sprayed with methanol gave the highest averages of yield and its components, followed by plants sprayed with CaBoron, while the plants sprayed with Pix came the last in these respects in both seasons. The positive effect of foliar feeding CaBoron and Humex (both contain K) on yield and its components may be due to that $\mathrm{K}$ is involved in many processes in the plant such as photosynthesis, respiration, carbohydrate metabolism, translocation and protein synthesis (Hearn, 1981). Similar results were obtained by El- Shazly et al. (2003) and Abdel Aal, et al (2011). The increment in seed cotton yield of pix-treated plants than untreated ones could mainly due to the higher number of open boll/plant which may be due to increasing boll retention per plant, where pix acts as a reducer to abscisic acid and a stimulator to IAA and cytokinin (Ibrahim and Moftah, 1997). The significant increments of seed cotton yield and its components due to foliar application of pix three times may be due to pix enhancement of boll retention and weight in the lower and middle parts of cotton plants (Ibrahim and Moftah, 1997).

\section{2.c. Interaction effect:}

Data presented in Table (4) show that the interaction between irrigation intervals and chemical treatments had a significant effect on number of open bolls /plant and seed cotton yield /fed. while it did not exhibit any significant effect in boll weight, seed index and lint \% in both seasons. Well watered plants every 15 day and sprayed with methanol gave the highest average in number of open bolls and seed cotton yield/fed. Gebaly (2007) found that Methanol application under water stress reduced the damage effect of water stress and to an increase in chlorophyll, carbohydrates and phenols contents in leaves, this caused an increase in open bolls/plant and boll weight. The water-stressed plants which treated with pix gave the lowest average in number of boll/plant and seed cotton yield. These results clear that sparing Pix under stress condition and high temperatures in Upper Egypt reduced boll number and yield due to the reduction in vegetative growth (plant height and number of fruiting branches).

\section{3- Fiber quality:}

\section{3.a. Effect of irrigation intervals:}

Data presented in Table (5) show that irrigation interval had a significant effect on upper half mean length, uniformity index and strength in both seasons but did not exhibit any significant effect on elongation \% and micronaire reading. Prolonging irrigation interval to 21 day significantly decreased upper half mean length, uniformity index and strength. Similar results were obtained by EL-Sayed (2005), Gebaly (2007) and Hamoda (2010). 
J. Plant Production, Mansoura Univ., Vol. 3 (3), March, 2012

5

503 


\section{3.b. Effect of drought tolerance inducers:}

Data in Table (5) also show that chemicals treatments had a significant effect on upper half mean length, uniformity index and fiber strength in both seasons and elongation \% and micronaire reading in the second season only. All chemical treatments (CaBoron, Humic acid, Pix and Methanol applications) gave the best average from the upper half mean length, uniformity index compared with the untreated plants. In general, plants which sprayed with Methanol gave the highest values of fiber length and uniformity index. Similar results were obtained by Gebaly (2007), while the CaBoron treatment gave the best fiber strength in both seasons.

\section{3.c. Interaction effect:}

The interaction between irrigation intervals and chemical treatments had a significant effect on fiber strength in both seasons and on upper half mean length in the first season only, (Table 4). Well watered plants every 15 day and sprayed with CaBoron treatment gave the highest average of fiber strength.

Finally It could be concluded from this study that the CaBoron, Humex, Pix and Methanol applications to plants under normal and water stress conditions had positive effects on performance of cotton plants, which increased plant growth, fruiting and yield especially under water stress conditions except Pix application under water stress condition and high temperature.

\section{REFERENCES}

Abd El-Aal, H.A., Makram, E.A. and Darwish, A.A. (1995). Effect of soil and foliar application potassium fertilizer timing on growth and yield of cotton (cultivar Giza 75). J. Agric. Sci. Mansoura Univ. 20 (5):19972004

Abdel-Aal, S.M.; Ibrahim, M.E.; Ali, A.A.; Wahdan, G.A.; Ali, O.A. and Ata Allah, Y.F. (2011). Effect of foliar application of growth regulators, macro and microelements on abscission, yield and technological characters of Egyptian cotton (Gossypium barbadense, L.). Minufiya J. Agric. Res., 36 (5): 1277-1304.

Abdel-Al, M.H. (1998). Effect of foliar methanol applications on Egyptian cotton plants Egypt J. Agric. Res., 76 (3): 1183-1196.

Ahmed, A.M. and Kassem, M.M.A. (2008). Cotton response to irrigation intervals under different levels of potassium and nitrogen. Assiut $\mathrm{J}$. of Agric. Sci., 39(5): 171-185

Ahmed, Fatma, M. (1994). The effect of some plant growth retardants on the mepiquat chloride under high nitrogen rates on productivity of cotton plant. Assiut J. Agric. Sci., 25 (4): 165-172.

Ashraf, M. and Foolad, M.R. (2007). Roles of glycine betaine and proline in improving plant a biotic stress resistance. Environmental and Experimental Botany 59 (2): $206-216$. 
A.S.T.M. (1986). American Society for Testing and Materials. D-4605., Vol. 07, No 1, Easton, MD, USA.

Barnes, C.E. and Houghton, W.E. (1994). Effect of Methanol application on Acala cotton in New Mexico. Proceeding Beltwide Cotton Conferences, January 5-8 San Diego, USA. 1343-1344

Blevins, D.G. and Lukaszewski, K.M. (1998). Boron in plant structure and function. Annu. Rev. Plant Pysiol. Mol. Biol., 49: 481-500.

Buttar, G. and Navneet, A. (2004). Growth retardants in cotton a review. J. Cotton Res., and Development, 18 (1): 61-69.

Chapman, H.D. and Pratt, P.P. (1978). Methods of analysis for soils, plants and water. Univ. of California, Div. of Agric. Sci. Priced Publ. 4034.

El-Beily, M.A.; El-Shazly, W.M.; Ali, S.A. and Ziadah, K.A. (2001). Response of cotton cultivar Giza 85 to nitrogen rates and hill spacing under levels of growth regulator (Pix). Minufiya J. Agric. Res., 26 (1): 51-84.

El-Menshawi, M.E. and El-Sayed, E.A. (2007). Some trails for increasing cotton yield by foliar application of some micronutrients. J. Agric. Sci. Mansoura Univ., 32(1): 1-9.

EL-Sayed, E.A. (2005). Effect of water stress and potassium fertilizer levels on growth and yield of cotton cultivar Giza 88. J. Agric. Sci., Mansoura Univ., 30 (1): 49-59.

El-Shazly, W.M.O.; Khalifa, R.K.M. and Nofal, O.A. (2003). Response of cotton Giza 89 cultivar to cotton cultivar to foliar spray with boron, potassium or a bioregulator SGA-1. Egypt J. Appl. Sci., 18(4B): 676699.

El-Tabbakh, S.S. (2002). Effect of mepiquat chloride concentrations on growth, productivity and fiber properties of two cotton cultivars (Gossypium spp.) under three nitrogen levels. Alexandria J. of Agric. Res., 47 (2): 45-59.

Etidal, T. Eid.; Abdel-Al, M.H.; M.S. Ismail and Wassel, O.M. (1997). Response of Egyption cotton to potassium and micronutrient application. Proc. FAO. IRCRNC, Joint Meeting of the Working Groups 4 \& 3 (Cotton Nutrition \& Growth Regulators), 20-23 March, 1995, Cairo, Egypt. Pp139-145

Gausman, H.W.; Escobar, D.E. and Rodriguez, R.R. (1981). Reflectance measurements of cotton leaf senescence altered by mepiquat chloride. Plant growth regulator bulletin 9 (4): 6-8 (c.f. Field Crop Abst. 39 (3): 2574, 1983).

Gebaly, Sanaa, G.; Namich, Alia, A. and Kassem, M.M (2008). Influence of mechanical topping and growth regulators on growth, yield and fiber properties of Egyptian cotton (Gossypium barbadense L.,) Minufiya J. Agric. Res., 33 (2): 445-455.

Girgis, E.A.; Abd El-Shafy, N.A. and El-Kashlan, M.K. (1993) Effect of using topping and cycocel under two levels of nitrogen on productivity of cotton cv. Giza 75. J. Agric. Res., Tanta Univ., 19 (2): 333-347.

Gomez, K.A. and Gomez, A.A. (1984). Statistical procedures for agriculture research. $2^{\text {nd }}$ Ed., John Willey and Sons, New York, USA.

Hamed, F.S. (2007). Response of cotton cultivar Giza 90 to water stress and potassium levels. Minia J. Agric. Res. \& Develop. , 27(2): 377-388. 
Hamoda, S. A. F.

Hamoda, S.A.F. (2010) Impact of water stress and nitrogen fertilizer levels on cotton grown under high temperature condations in Upper Egypt. Minufiya J. Agric. Res. 35 (5):1797-1814

Hearn, A.B. (1981). Cotton nutrition. Field Crop Abst., 34 (1): 11.34.

Ibrahim, M.E. and Moftah, A.E. (1997). The response of cotton plants to frequent irrigation and mepiquat chloride (pix). Minufiya J. Agric. Res., 22 (3): 723-754.

Kassem, M.A. and Namich, Alia, A. (2003). Response of cotton cultivar Giza 83 to mepiquat chloride (Pix) under two levels of irrigation intervals. Egypt. J. Appl. Sci., 18 (5): 105-121.

Kassem, M.M.A.; Emara, M.A.A. and Hamoda, S.A.F. (2009). Growth and productivity of Giza 80 cotton cultivar as affected by foliar feeding with boron and zinc. J. Agric. Sci. Mansoura Univ., 34 (2): 967 - 975

Kumar, K.A.; Patil, B.C. and Chetti, M.B. (2005). Effect of plant growth regulators on physiological components of yield in hybrid cotton. Indian J. Plant Physiology. 10 (2): 187-190.

Makram, E.A.; Darwish, A.A. and El-Shazly, W.M. (1996). Irrigation frequency in relation to growth and yield Giza 75 cotton cultivar. Minufiya J. Agric. Res., 21: 581-590.

Meek, C.; Oosterhis, D. and Gorham, J. (2003). Does foliar applied glycine betaine effect endogenous betaine levels and yield in cotton on line. Crop Management doi. 10 - 1904 / CM -2003-0804-02- RS.

Moseley, D.; LanDiver, J.A. and Locke, D. (1994). Evaluation of effect of methanol on growth, and yield, under dry land and irrigated condations. Proceeding Beltwide Cotton Conferences, January 5-8 San Diego, USA. 1293-1294

Muhammad, I.; Khezir, H. and Nor-ul-islam, M. (2007). Cotton response to mepiquat chloride and nitrogen under ultra narrow plant spacing. Asian J. Plant Sci., 6 (1):87-92

Niaz, A.; Ibrahim, M.; Ahmed, N. and Anwar, A. (2002). Boron contents of light and medium texture soils and cotton plants. Inter. J. Agric.\& Biol., 4(4):534-536.

Nonomura, A.M. and Benson A.A. (1992). The path of carbon in photosynthesis, Improved Crop Yield with Methanol. Proc. Nat. Acad. Sci., USA. 89:794-979

Reddy, K.R.; Hodges, H.F. and McKinion, J.M. (1998). Photosynthesis and environmental factors. Proceed. Beltwide Cotton Conf., pp. 1443-1450.

Reddy, V.R.; Baker, D.N. and Hadges, H.F. (1990). Temperature and mepiquat chloride effects on cotton canopy architecture. Agron. J., 82 (2): 190-195.

Roberts, R.K.; Gersman, J.M. and Howard, D.D. (2000). Soil and foliar applied boron in cotton production: An economic analysis. The J. Cotton Sci. 4: 171-177.

Saeed, M.A. (2000). Physiological response of cotton cultivar Giza 80 to foliar spray of boron. Minufiya J. Agric. Res., 25(5): 1185-1197.

Xiong, L. and J.K. Zhu (2002). Molecular and genetic aspects of plant responses to osmotic stress. Plant, Cell and Environment, 25:131-139. 
Zhao, D. and D.M. Oosterhuis 2003. Cotton growth and physiological response to boron deficiency. J. Plant Nutrition, 26(4): 855-867.

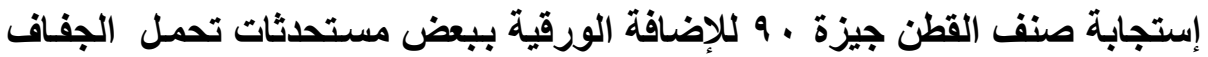

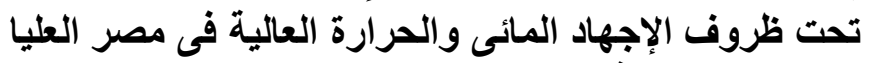

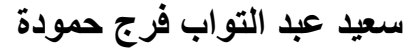
قسم بحوث المعاملات الزراعية ـ معهد بحوث القطن ـ مركز البحوث الزراعية ـ الجيزة ـ مصر.

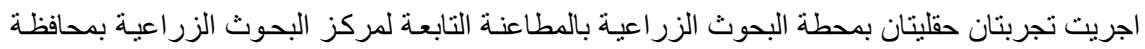

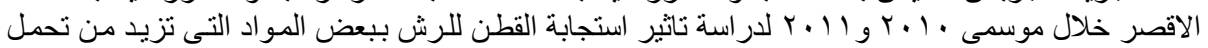

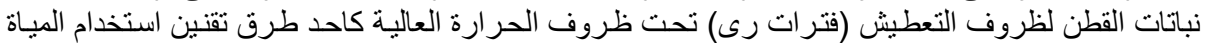

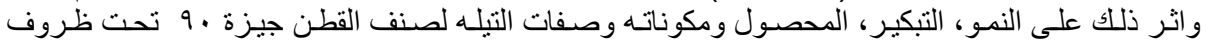

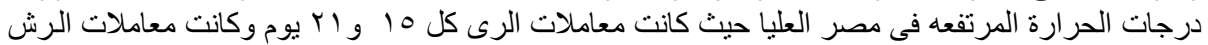

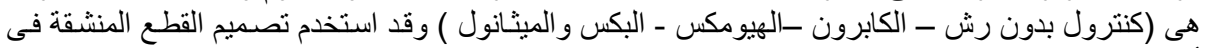

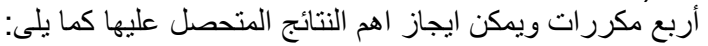

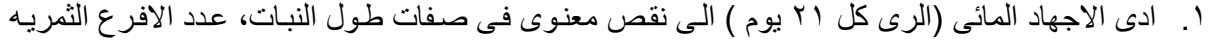

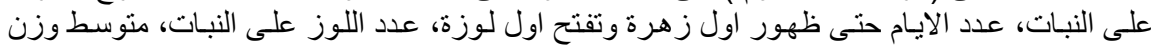

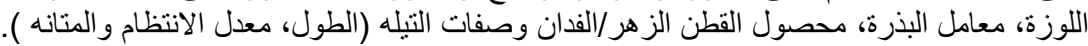

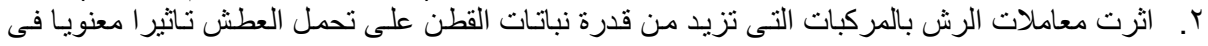

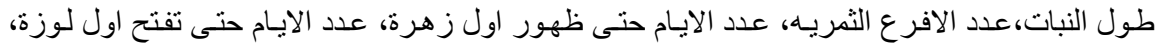

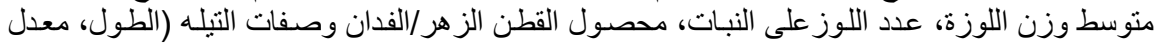
الانتظام و المتانه ). الرزة.

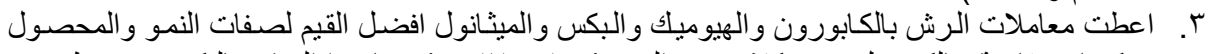

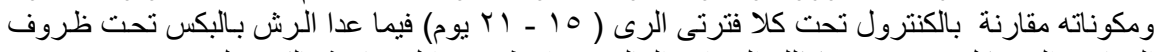

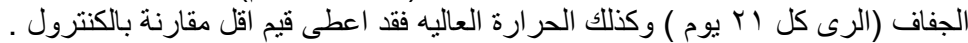

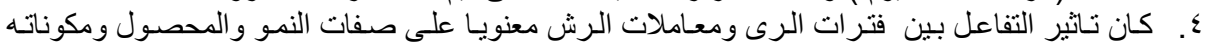

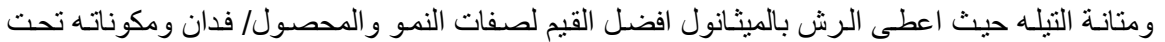
الرى كل 10 يوم بينما اعطى الرش بالكابورون افضل القئ القيم لنتانة التيله تحت نفس مستوى الرى.

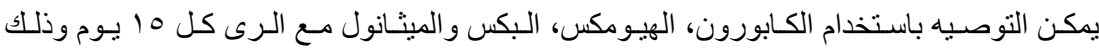

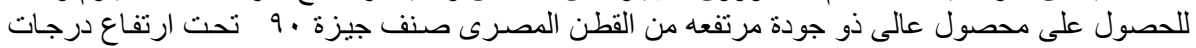

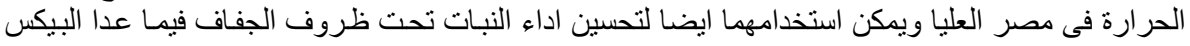

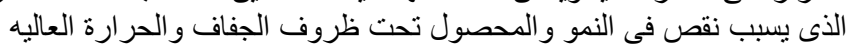

كلية الزراعة - جامعة المنصورة كلية الزراعة - جامعة الزقازيق

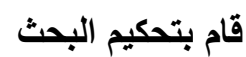

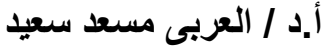

أ.د / احمد انور عبد الجليل ميليل 

J. Plant Production, Mansoura Univ., Vol. 3 (3): 493 - 507, 2012 

Table (3): Effect of irrigation intervals, chemicals applications and their interaction on growth parameters and earliness traits of Giza 90 cotton variety during 2010 and 2011 seasons in Upper Egypt

\begin{tabular}{|c|c|c|c|c|c|c|c|c|c|c|c|c|c|}
\hline \multicolumn{2}{|c|}{ Treatments } & \multicolumn{4}{|c|}{ Growth parameters } & \multicolumn{8}{|c|}{ Earliness traits } \\
\hline \multirow{2}{*}{$\begin{array}{l}\text { Irrigation } \\
\text { intervals } \\
\text { (A) }\end{array}$} & \multirow{2}{*}{$\begin{array}{c}\text { Chemical } \\
\text { applications (B) }\end{array}$} & \multicolumn{2}{|c|}{ Plant height (cm) } & \multicolumn{2}{|c|}{$\begin{array}{l}\text { No. of fruiting } \\
\text { branches / plant }\end{array}$} & \multicolumn{2}{|c|}{$\begin{array}{l}\text { First fruiting } \\
\text { node }\end{array}$} & \multicolumn{2}{|c|}{$\begin{array}{l}\text { Days to first } \\
\text { flower }\end{array}$} & \multicolumn{2}{|c|}{$\begin{array}{l}\text { Days to first } \\
\text { open boll }\end{array}$} & \multicolumn{2}{|c|}{ Earliness \% } \\
\hline & & 2010 & 2011 & 2010 & 2011 & 2010 & 2011 & 2010 & 2011 & 2010 & 2011 & 2010 & 2011 \\
\hline \multirow{5}{*}{15 day } & Control & 137.00 & 135.00 & 12.33 & 12.90 & 6.10 & 6.27 & 62.00 & 66.00 & 111.25 & 114.50 & 68.02 & 62.61 \\
\hline & CaBoron & 139.23 & 136.67 & 13.17 & 13.50 & 5.83 & 6.33 & 62.50 & 66.25 & 110.00 & 114.50 & 72.06 & 65.47 \\
\hline & Humex & 139.53 & 138.57 & 12.57 & 13.33 & 6.10 & 6.30 & 62.50 & 66.00 & 110.25 & 116.00 & 72.56 & 64.17 \\
\hline & Pix & 130.33 & 132.73 & 12.97 & 13.60 & 6.10 & 6.13 & 62.75 & 66.00 & 112.50 & 114.25 & 71.54 & 64.16 \\
\hline & Methanol & 137.20 & 137.73 & 13.60 & 13.90 & 6.20 & 6.40 & 62.75 & 66.50 & 111.75 & 114.75 & 75.53 & 67.07 \\
\hline \multicolumn{2}{|l|}{ Mean } & 136.66 & 136.14 & 12.93 & 13.45 & 6.07 & 6.29 & 62.50 & 66.15 & 111.15 & 114.80 & 71.94 & 64.70 \\
\hline \multirow{5}{*}{21 day } & Control & 130.37 & 125.13 & 10.53 & 12.13 & 7.47 & 6.63 & 58.75 & 64.50 & 108.75 & 112.00 & 73.77 & 65.74 \\
\hline & CaBoron & 133.67 & 128.77 & 11.10 & 12.70 & 7.80 & 6.50 & 59.25 & 64.25 & 108.00 & 112.00 & 74.35 & 67.57 \\
\hline & Humex & 134.33 & 128.50 & 10.90 & 12.77 & 7.27 & 6.63 & 59.50 & 64.75 & 108.50 & 112.00 & 74.46 & 66.17 \\
\hline & Pix & 125.00 & 118.07 & 10.06 & 11.57 & 7.30 & 6.73 & 60.75 & 65.00 & 108.25 & 112.50 & 75.53 & 67.75 \\
\hline & Methanol & 132.67 & 125.90 & 11.37 & 12.80 & 7.37 & 6.77 & 59.75 & 64.50 & 108.00 & 112.75 & 77.30 & 69.13 \\
\hline \multicolumn{2}{|l|}{ Mean } & 131.21 & 125.27 & 10.79 & 12.39 & 7.44 & 6.65 & 59.60 & 64.60 & 108.30 & 112.25 & 75.08 & 67.27 \\
\hline \multirow{5}{*}{$\begin{array}{l}\text { General } \\
\text { of (B) }\end{array}$} & Control & 133.68 & 130.07 & 11.43 & 12.52 & 6.78 & 6.45 & 60.38 & 65.25 & 110.00 & 113.25 & 70.90 & 64.18 \\
\hline & CaBoron & 136.45 & 132.72 & 12.13 & 13.10 & 6.82 & 6.42 & 60.88 & 65.25 & 109.00 & 113.25 & 73.20 & 66.52 \\
\hline & Humex & 136.93 & 133.53 & 11.73 & 13.05 & 6.68 & 6.47 & 61.00 & 65.38 & 109.38 & 114.00 & 73.51 & 65.17 \\
\hline & Pix & 127.67 & 125.40 & 11.51 & 12.58 & 6.70 & 6.43 & 61.75 & 65.50 & 110.38 & 113.38 & 73.54 & 65.96 \\
\hline & Methanol & 134.93 & 131.82 & 12.48 & 13.35 & 6.78 & 6.58 & 61.25 & 65.50 & 109.88 & 113.75 & 76.42 & 68.10 \\
\hline \multirow{3}{*}{ LSD at 0.05 for } & A & 0.91 & 0.30 & 0.29 & 0.12 & 0.17 & 0.25 & 0.69 & 0.88 & 0.68 & 0.38 & 0.74 & 0.17 \\
\hline & $B$ & 0.62 & 0.28 & 0.34 & 0.16 & N.S & N.S & 0.72 & N.S & 0.49 & 0.59 & 0.31 & 0.28 \\
\hline & $A \times B$ & 0.88 & 0.81 & 0.48 & 0.22 & N.S & N.S & NS & NS & 0.69 & 0.84 & 0.43 & 0.40 \\
\hline
\end{tabular}


Hamoda, S. A. F.

Table (4): Effect of irrigation intervals, chemicals applications and their interaction on yield and yield components of Giza 90 cotton variety during 2010 and 2011 seasons in Upper Egypt

\begin{tabular}{|c|c|c|c|c|c|c|c|c|c|c|c|}
\hline \multicolumn{2}{|c|}{ Treatments } & \multirow{2}{*}{\multicolumn{2}{|c|}{$\begin{array}{l}\text { Boll weight } \\
\text { (g) }\end{array}$}} & \multirow{2}{*}{\multicolumn{2}{|c|}{$\begin{array}{c}\text { No. of open } \\
\text { bolls/plant }\end{array}$}} & \multirow{2}{*}{\multicolumn{2}{|c|}{$\begin{array}{c}\text { Seed index } \\
(\mathrm{g})\end{array}$}} & \multirow{2}{*}{\multicolumn{2}{|c|}{$\underset{\%}{\operatorname{Lint}}$}} & \multirow{2}{*}{\multicolumn{2}{|c|}{$\begin{array}{l}\text { Seed cotton yield } \\
\text { (ken. /fed.) }\end{array}$}} \\
\hline \multirow{2}{*}{$\begin{array}{c}\text { Irrigation } \\
\text { intervals (A) }\end{array}$} & \multirow{2}{*}{$\begin{array}{c}\text { Chemicals } \\
\text { applications (B) }\end{array}$} & & & & & & & & & & \\
\hline & & 2010 & 2011 & 2010 & 2011 & 2010 & 2011 & 2010 & 2011 & 2010 & 2011 \\
\hline \multirow{5}{*}{15 day } & Control & 2.45 & 2.39 & 14.70 & 15.34 & 9.83 & 10.00 & 36.64 & 36.61 & 11.23 & 11.61 \\
\hline & CaBoron & 2.51 & 2.45 & 16.80 & 17.24 & 9.93 & 10.14 & 36.65 & 36.92 & 12.28 & 12.43 \\
\hline & Humex & 2.53 & 2.44 & 16.35 & 17.39 & 9.96 & 10.12 & 36.67 & 37.19 & 12.14 & 12.71 \\
\hline & Pix & 2.49 & 2.42 & 16.07 & 17.6 & 9.90 & 10.00 & 36.37 & 36.48 & 12.18 & 12.58 \\
\hline & Methanol & 2.53 & 2.45 & 17.85 & 17.90 & 10.07 & 10.05 & 36.83 & 36.67 & 12.93 & 13.52 \\
\hline \multicolumn{2}{|l|}{ Mean } & 2.50 & 2.43 & 16.35 & 17.01 & 9.94 & 10.06 & 36.63 & 36.77 & 1.15 & 12.57 \\
\hline \multirow{5}{*}{21 day } & Control & 2.35 & 2.31 & 12.90 & 13.16 & 9.30 & 9.43 & 36.97 & 36.98 & 9.31 & 9.51 \\
\hline & CaBoron & 2.42 & 2.34 & 13.82 & 13.94 & 9.37 & 9.73 & 37.08 & 37.09 & 10.25 & 10.32 \\
\hline & Humex & 2.39 & 2.32 & 13.23 & 13.65 & 9.41 & 9.54 & 37.20 & 37.34 & 9.66 & 10.05 \\
\hline & Pix & 2.43 & 2.63 & 11.55 & 12.31 & 9.35 & 9.43 & 37.07 & 36.58 & 8.52 & 8.86 \\
\hline & Methanol & 2.45 & 2.69 & 14.28 & 14.67 & 9.46 & 9.61 & 37.39 & 37.20 & 10.45 & 10.93 \\
\hline \multicolumn{2}{|l|}{ Mean } & 2.41 & 2.46 & 13.16 & 13.55 & 9.38 & 9.55 & 37.14 & 37.04 & 9.64 & 9.93 \\
\hline \multirow{5}{*}{$\begin{array}{l}\text { General mean } \\
\text { (B) }\end{array}$} & Control & 2.40 & 2.35 & 13.80 & 14.25 & 9.57 & 9.71 & 36.81 & 36.80 & 10.27 & 10.56 \\
\hline & CaBoron & 2.47 & 2.40 & 15.31 & 15.59 & 9.65 & 9.94 & 36.87 & 37.00 & 11.27 & 11.38 \\
\hline & Humex & 2.46 & 2.38 & 14.79 & 15.52 & 9.69 & 9.83 & 36.93 & 37.26 & 10.90 & 11.38 \\
\hline & Pix & 2.46 & 2.53 & 13.81 & 14.74 & 9.63 & 9.72 & 36.72 & 36.53 & 10.35 & 10.72 \\
\hline & Methanol & 2.49 & 2.57 & 16.07 & 16.28 & 9.77 & 9.83 & 37.11 & 36.93 & 11.69 & 12.22 \\
\hline \multirow{3}{*}{ LSD at 0.05 for } & $\mathbf{A}$ & 0.03 & 0.02 & 0.18 & 0.13 & 0.01 & 0.07 & 0.20 & 0.15 & 0.05 & 0.20 \\
\hline & B & 0.04 & 0.02 & 0.21 & 0.14 & 0.03 & 0.09 & 0.23 & 0.12 & 0.10 & 0.09 \\
\hline & $A \times B$ & N.S & N.S & 0.30 & 0.20 & N.S & N.S & N.S & N.S & 0.14 & 0.13 \\
\hline
\end{tabular}


Table (5): Effect of irrigation intervals, chemicals treatments and their interaction on fiber properties of Giza 90 cotton variety during 2010 and 2011 seasons in Upper Egypt

\begin{tabular}{|c|c|c|c|c|c|c|c|c|c|c|c|}
\hline \multicolumn{2}{|l|}{ Treatments } & \multicolumn{4}{|c|}{ Fiber length parameters } & \multicolumn{4}{|c|}{ Fiber bundle tensile } & \multirow{2}{*}{\multicolumn{2}{|c|}{$\begin{array}{l}\text { Mic. } \\
\text { reading }\end{array}$}} \\
\hline \multirow{2}{*}{$\begin{array}{l}\text { Irrigation } \\
\text { intervals (A) }\end{array}$} & \multirow{2}{*}{$\begin{array}{l}\text { Chemical } \\
\text { applications (B) }\end{array}$} & \multicolumn{2}{|c|}{$\begin{array}{l}\text { Upper half mean } \\
\text { (U.H.M) }\end{array}$} & \multicolumn{2}{|c|}{$\begin{array}{c}\text { Uniformity } \\
\text { index }\end{array}$} & \multicolumn{2}{|c|}{$\begin{array}{l}\text { Strength } \\
\text { g/tex }\end{array}$} & \multicolumn{2}{|c|}{$\begin{array}{c}\text { Elongation } \\
\%\end{array}$} & & \\
\hline & & 2010 & 2011 & 2010 & 2011 & 2010 & 2011 & 2010 & 2011 & 2010 & 2011 \\
\hline \multirow{5}{*}{15 day } & Control & 30.53 & 30.63 & 85.80 & 85.40 & 35.53 & 35.30 & 7.90 & 8.00 & 4.30 & 4.30 \\
\hline & CaBoron & 30.63 & 30.77 & 86.00 & 86.20 & 39.90 & 38.40 & 7.73 & 7.70 & 4.40 & 4.50 \\
\hline & Humex & 31.17 & 31.17 & 85.77 & 85.9 & 37.83 & 38.10 & 7.63 & 7.80 & 4.40 & 4.40 \\
\hline & Pix & 31.10 & 30.77 & 85.83 & 85.57 & 35.47 & 35.20 & 7.80 & 7.90 & 4.43 & 4.30 \\
\hline & Methanol & 31.33 & 31.50 & 86.00 & 86.10 & 36.78 & 35.93 & 7.63 & 7.60 & 4.30 & 4.40 \\
\hline \multicolumn{2}{|l|}{ Mean } & 30.95 & 30.97 & 85.88 & 85.83 & 37.10 & 36.59 & 7.74 & 7.80 & 4.37 & 4.38 \\
\hline \multirow{5}{*}{21 day } & Control & 29.70 & 30.10 & 85.40 & 85.20 & 35.27 & 35.07 & 8.00 & 7.80 & 4.33 & 4.20 \\
\hline & CaBoron & 30.53 & 30.47 & 85.47 & 85.70 & 37.80 & 38.00 & 7.83 & 7.60 & 4.40 & 4.40 \\
\hline & Humex & 30.17 & 30.60 & 85.43 & 85.80 & 37.00 & 37.50 & 7.70 & 7.60 & 4.27 & 4.20 \\
\hline & Pix & 30.13 & 30.07 & 85.47 & 85.60 & 36.10 & 35.30 & 7.87 & 7.70 & 4.40 & 4.20 \\
\hline & Methanol & 30.43 & 30.83 & 86.03 & 85.90 & 35.73 & 35.80 & 7.70 & 7.70 & 4.30 & 4.40 \\
\hline \multicolumn{2}{|l|}{ Mean } & 30.19 & 30.41 & 85.56 & 85.64 & 36.38 & 36.33 & 7.82 & 7.68 & 4.34 & 4.30 \\
\hline \multirow{5}{*}{$\begin{array}{l}\text { General mean o } \\
\text { (B) }\end{array}$} & Control & 30.12 & 30.37 & 85.60 & 85.30 & 35.40 & 35.18 & 7.95 & 7.90 & 4.32 & 4.25 \\
\hline & CaBoron & 30.58 & 30.62 & 85.73 & 85.95 & 38.85 & 38.20 & 7.78 & 7.65 & 4.40 & 4.45 \\
\hline & Humex & 30.67 & 30.88 & 85.60 & 85.85 & 37.42 & 37.80 & 7.67 & 7.70 & 4.33 & 4.35 \\
\hline & Pix & 30.62 & 30.42 & 85.65 & 85.58 & 35.78 & 35.25 & 7.83 & 7.80 & 4.42 & 4.25 \\
\hline & Methanol & 30.88 & 31.17 & 86.02 & 86.00 & 36.25 & 35.87 & 7.67 & 7.65 & 4.30 & 4.40 \\
\hline \multirow{3}{*}{ LSD at 0.05 for } & A & 0.35 & 0.15 & 0.20 & 0.10 & 0.44 & 0.16 & N.S & N.S & N.S & N.S \\
\hline & $B$ & 0.17 & 0.20 & 0.25 & 0.17 & 0.68 & 0.15 & N.S & 0.17 & N.S & 0.11 \\
\hline & $A \times B$ & 0.24 & N.S & N.S & N.S & 0.96 & 0.22 & N.S & N.S & N.S & N.S \\
\hline
\end{tabular}

